
3 Research Square
Preprints are preliminary reports that have not undergone peer review.
They should not be considered conclusive, used to inform clinical practice, or referenced by the media as validated information

\title{
An ethnobotanical study of wild edible plants in Yilmana Densa and Quarit Districts, West Gojjam, Western Ethiopia
}

Derebe Alemneh ( $\sim$ derebealemneh333@yahoo.com)

Assosa University

Research

Keywords: Conservation, edible part, fruit, habit, threat

Posted Date: September 9th, 2020

DOI: https://doi.org/10.21203/rs.3.rs-70088/v1

License: (9) (7) This work is licensed under a Creative Commons Attribution 4.0 International License. Read Full License 


\section{Abstract}

Backgrounds: Globally, wild edible plants are one of the main non-timber forest products and possess up to $96 \%$ of the value of forests. They are an essential source of supplementary foods in many parts of Ethiopia. However, they have been highly degraded and lost due to anthropogenic factors. Thus, current study aims at recording and documenting wild edible plants in Yilmana Densa and Quarit Districts, West Gojjam, Western Ethiopia to pave a way for further research and conservation.

Methods: Semi-structured interviews, focus group discussions, participant observation and market survey were the data collection tools. Preference and direct matrix ranking were used to analyze the data.

Results: Thirty two wild edible plant species were reported in the two Districts. Most of the species were herbs while the major (53.1\%) edible parts were fruits. Most of the collectors of the wild food were young males. Ficus sur was the most preferred wild edible plant.

Conclusion: The districts are still rich sources of wild edible plants. However, there was low potential of conservation. Therefore, there should be extensive awareness rising for wild edible plant conservation.

\section{Background}

Wild edible plants one of the main non-timber forest products and possess up to $96 \%$ of the value of forests as UN estimates [1]. They are the crucial source of wild foods for pastoralists, shifting cultivators, continuous croppers and hunter gatherers in rural areas [2]. About one billion people of the world use wild edible plants to complement their nutrients in their diet to improve the deliciousness of staple foods [3]. Wild edible food also used to diversify food sources, mitigate malnutrition, and generate alternative incomes, especially, at times of critical food shortages due to any catastrophes like droughts, as well as during famines brought by market fluctuations and political unrest $[4,5]$.

African populations, especially poor households in rural areas, have depended on wild edible plants to reduce spending of limited cash resources on energy, shelter, food and medication [6]. Moreover, they are the source of traditional knowledge systems [7].The people of Ethiopia, especially the rural people, have a good knowledge on the use of wild edible plants due to the presence of a common consumption practice in the country [8]. However, the process of collection of wild edible plants may be difficult if there are no local management systems and national policies that ensure their sustainable availability in their wild habitats [1, 5]. However, in Ethiopia there is high vegetation dwindling from time to time due to anthropogenic factors [9]. Thus, recording and documenting wild edible plants and the associated indigenous knowledge are crucial for the conservation of the species.

\section{Methods}

\section{Study area description}

Yilmana Densa District (Woreda) is located at $11^{\circ} 30^{\square} 0^{\square} \mathrm{N}$ and $37^{\circ} 20^{\llbracket 0} 0^{\square} \mathrm{E}$ in West Gojjam Zone (Fig. 2). It is bordered on the East by Abay River which separates it from the south Gondar Zone. The major town of this District, Adet, is 42 kilo meters far from Bahir Dar which is the capital of Amhara region. Quarit District is located at $11^{\circ} 10^{\llbracket 0} 0^{\square} \mathrm{N}$ and $37^{\circ} 15^{\llbracket} 0^{\square} \mathrm{E}$ in West Gojjam Zone, and it is bordered on the north by Yilmana Densa and on the east by East Gojjam Zone. The major town of the district is Gebez Maryam. Both Yilmana Densa and Quarit Districts have Weyna Dega and Dega agroclimatic Zones.

Approximately, 75.75\% of Yilmana Densa District is Dega agroclimatic Zone [10,11]. The main rainy seasons in both districts are May to October (Fig. 1). Both Districts have plains, mountains, valleys and undulating areas that consist of $16,20,8$ and 56 percent of the area respectively. The soils are moderately fertile and they are traditionally classified into black soil, red soil and brown soil that consist of 20, 65 and 15 percent of the soil of the District respectively [11].

According to [12], Yilmana Densa District has a total population of 214,852, of whom 107,010 are males and 107,842 females; 19,169 or $8.92 \%$ are urban inhabitants. The majority (98.19\%) of the inhabitants practiced Ethiopian Orthodox Christianity while $1.76 \%$ was Muslim. The largest ethnic group reported in the District was Amhara (99.94\%). Amharic was spoken as a first language by $99.96 \%$. Quarit District has a total population of 114,771 . Among the total population, 56,767 are males and 58,004 are females respectively. The majority of the population resides in rural areas where as $4.14 \%$ are urban inhabitants. A population density of Quarit is 190.34 with a total area of 602.99 square kilometers. The District has also 25,402 households those result an average of 4.52 persons to a household, and 24,927 housing units. The District is inhabited by $99.9 \%$ of Amhara people, and $99.96 \%$ of the residents are practicing Ethiopian Orthodox Christianity.

\section{Site selection and sampling method}

The sites were selected during reconnaissance survey by discussing with the Districts' administrators, the residence of the Kebeles, agricultural professionals, rural teachers, and by observation. Following the discussion twelve rural Kebeles from Yilmana Densa District and seven rural Kebeles from Quarit District were selected (Fig. 3). The sample Kebeles of each District and the key informants were selected purposively whereas the general informants were selected using systematic random sampling method. The 19 rural Kebeles were selected based on the presence of relatively dominant vegetation covers. For the determination of the sample size of the two Districts, the following formula was applied:

$$
\mathrm{n}=\frac{\mathrm{N}}{1+\mathrm{N}(\mathrm{e})^{2}}
$$


Where $\mathrm{n}$ is the sample size, $\mathrm{N}$ is the population size (total number of households of the two Districts), and e (e=0.05) is the level of precision. This formula is a simplified way used to calculate the sample sizes at $95 \%$ confidence level and $P=0$ [13]. After determining the amount of informants for the study, representative general and key informants of the Districts were selected using systematic random and purposive sampling (based on their relative better knowledge) approaches respectively as described by [14] and [15].

Therefore, the total number of general informants involved in ethnobotanical survey of wild edible plants of the Districts having two agroclimatic Zones (Weyna Dega and Dega) was 268 males and 127 females, separately 102 men and 45 women from Quarit District, and 165 men and 83 women informants from Yilmana Densa District respectively. Peer recommendations from community members, elderly people and knowledgeable inhabitants helped in nominating 95 key informants ( 68 men and 27 women). Separately 35 ( 25 men and 10 women) were from Quarit District and 60 (43 men and 17 women) were from Yilmana Densa District. The age of the general informants ranged from 20-81 years (139 were from 20-40 whereas 256 were $>40$ years old). Informed consent was obtained from each informant who participated in this study after explaining the purpose of the study and assuring him/her of the most responsible legal use of information before the start of interviews.

\section{Data Collection}

Data were collected in different seasons over different years with the objective of including different Kebeles found in the two agroclimatic Zones of the Districts, and collecting plant specimens during the respective flowering seasons. Ethnobotanical data were collected during four different field visits conducted between 15 September 2016 and 30 June 2018. Market surveys were conducted between 10 December 2017 and 7 May 2018. Semi-structured interviews, focus group discussions, field observation and market survey were used to collect ethnobotanical data in the manner recommended by [14].

A semi-structured interview and focus group discussion were by using a checklist of questions prepared before hand in English, and presented by translating into Amharic which is the common language of the local community. Informants were interviewed individually in the local Amharic language. All semistructured interviews were followed by independent walk in the woods exercises to pave a way for a detailed discussion with the informant and the practical identification of traditionally used wild edible plants in the natural environment.

Field observations were performed with the help of local guides, as well as some respondents of the local community. In addition, one focus group discussion (consisting of 7 participants) per Kebele was undertaken to gain detailed information on wild edible plants knowledge at the community level and to supplement the information collected through semi-structured interviews. The informants were asked about local names, habitats, parts used, the threats and traditional conservation practices of wild edible plants $[16,17]$. The informants were also asked about over all use values of wild edible plants $[16]$.

\section{Preference Ranking And Direct Matrix Ranking}

Data on use diversity of five multipurpose wild edible plants was evaluated by direct matrix ranking exercise. This involved six (four men and two women) key informants selected from both Districts as stated by [14]. The purpose of this exercise was to identify which of the multipurpose plants is most under pressure in the area and to evidence the corresponding factors that threaten plants. Participants were asked to assign values to different uses of wild edible plant species as firewood, construction, agricultural tool, medicine, charcoal, timber, food and fence, and based on the degree of uses (i.e. $5=$ best; $4=$ very good; $3=$ good; 2 = less used; 1 = least used and 0 = no value). By adding the scores, it was possible to compare the multipurpose wild edible plants to identify the main contributing factor to the loss of respective species [17]. Sixteen key informants from two Districts were also involved to rank 8 wild edible plants (Dovyalis abyssinica, Rubus apetalus, Ficus sur, Cordia africana, Carissa spinarium, Rosa abyssinica, Ficus vasta and Rhus glutinosa) regarding their taste quality and income generation based on the personal preference or perceptions of the key informants following the procedure elucidated by [14] and [17]. Each rank was given a value of $1,2,3,4,5,6,7$ and 8 . The procedure was stated by [14].

\section{Use diversity study}

Ethnobotanical data obtained using various ethnobotanical data collection methods were all documented to assess overall use values and use diversity of species following [18] and [19]. All informants of the study were interviewed at the same time for their knowledge on additional local use or use diversity of plants cited for one or more uses following the method of $[14,17]$. Six key informants were also involved for direct matrix exercise of five wild edible plants (Acacia abyssinica, Carissa spinarum, Cordia africana, Olea europaea subsp. cuspidata and Rosa abyssincia) with additional uses (environmental use, forage, fuel, medicine and social use). These species were ranked based on five use criteria ( 5 = Best; 4 = Very good; $3=$ Good; $2=$ Less used; $1=$ Least used and $0=$ No value). For exercise of direct matrix ranking focus group discussion (FGD) was conducted to know the degree of preference based on multipurpose criteria on the plants. The method of descriptive statistics was also applied to identify the number and percentage of species, genera and families of wild edible plants used, their growth forms, proportions of parts used.

\section{Market Surveys}

Market surveys were conducted at Adet, Dabi and Bir Gebeya whose market date is going on Saturday and Wednesday for the first two and Friday for the later respectively. The purpose of market survey was to record, document and analyze the availability, price and unit of measurement, extent of use and income generating potential of wild edible plants found in these markets following the method of [16].

\section{Results And Discussions}

\section{Habits and edible parts}

The districts harbored 32 wild edible plants under 24 families (Table 1). The species were recorded with 3 habit classes namely herbs, shrubs and trees. Most of wild food sources were herbs as reported by the local people whereas fruits were the major edible parts of the species out of 9 reported edible parts (Fig. 1). 
The reason for preference of fruits as the primary source of wild food might be due to their possession of highest nutritional value than other edible parts [20, 21]. The results of the nutritional analysis of the fruits of some wild edible plants indicated that fruits contain appreciable amount of nutrients and energy that are useful for food supplements [22, 23].

Table 1

Wild edible plants and edible parts

\begin{tabular}{|c|c|c|}
\hline Scientific name & Family & Edible parts \\
\hline Acacia abyssinica Hochst. & Fabaceae & Resin \\
\hline Acanthus sennii Chiov & Acanthaceae & Nectar \\
\hline Carissa spinarum L. & Apocynaceae & Fruit \\
\hline Commelina spp. & Commelinaceae & Root \\
\hline Cordia africana merican Lam. & Boraginaceae & Fruit \\
\hline Cynodon dactylon (L.) Pers. & Poaceae & Stem \\
\hline Cyperus rigidifolius Steud & Cyperaceae & Stolon \\
\hline Datura stramonium $\mathrm{L}$. & Solanaceae & Nectar \\
\hline Dovyalis abyssinica (A. Rich.) Warb. & Flacourtiaceae & Fruit \\
\hline Embelia schimperi Vatke & Myrsinaceae & Fruit \\
\hline Ensete ventricosum (Welw.) Cheesman & Musaceae & Fruit \\
\hline Ferula communis $\mathrm{L}$. & Apiaceae & Leaf \\
\hline Ficus surForssk. & Moraceae & Fig \\
\hline Ficus vasta Forssk & Moraceae & Fig \\
\hline Hagenia abyssinica (Bruce) J.F. Gmelin & Rosaceae & Fruit \\
\hline Mimusops kummel A. DC. & Sapotaceae & Fruit \\
\hline Ocimum urticifolium Roth & Lamiaceae & Leaf \\
\hline Olea europaea L. subsp. cuspidata & Oleaceae & Leaf, fruit \\
\hline Opuntia ficus-indica (L.) Miller. & Cactaceae & Fruit \\
\hline Persicaria nepalensis (Mesin.) Miyabe & Polygonaceae & Stem \\
\hline Rhus glutinosa A. Rich. & Anacardiaceae & Fruit \\
\hline Rosa abyssincia Lindley. & Rosaceae & Fruit \\
\hline Rubus apetalus Poir. & Rosaceae & Fruit \\
\hline Rumex abyssinicus Jacq. & Polygonaceae & Root \\
\hline Rumex nervosus Vahl & Polygonaceae & Stem, Leaf \\
\hline Solanum nigrum $\mathrm{L}$. & Solanaceae & Fruit \\
\hline Syzygium guineense (Wild.) DC. & Myrtaceae & Fruit \\
\hline Thymus schimperi Ron. & Lamiaceae & Leaf \\
\hline Trifolium schimperi A. Rich. & Fabaceae & Fruit \\
\hline Urtica simensis Steudel & Urticaceae & Leaf \\
\hline Vernonia amygdalina Del. & Asteraceae & Leaf \\
\hline Ximenia americana L. & Olacaceae & Fruit \\
\hline
\end{tabular}

\section{Collection Sites And Collecting Households}

Farmlands, grazing lands, roadsides, forests and home gardens were reported to be the major sites of collection in the districts. However, Urtica simensis, Vernonia amygdalina, Cordia Africana and Ensete ventricosum were reserved only in home gardens. Most species of wild edible plants were reported to be non-managed by the local community directly as complementary food in the districts. The results also showed that most of the wild foods were collected by young males especially by shepherds. It was reported to be because of the following reasons: 1) as it was reported, there was a division of labor in the family members. That means females usually work in the house whereas males might mostly work outside their houses. This might enable males to be more experienced with wild edible foods. Moreover, most of the shepherds were reported to be young males that might experience hungry since they might be far 
from their houses. 2) Males might have better ability to climb and grip mature tallest trees than females. Thus, more burden of collection might lie down on males than females.

\section{Use Preference}

Ficus sur was recorded to be the most preferred wild edible plant with total score of 111 (Table 2) because its figs are sweet. In addition, the figs were the most preferred marketable wild foods for income generation.

Table 2

Preference ranking of 8 wild edible plants based on taste by 16 key informants

\begin{tabular}{|c|c|c|c|c|c|c|c|c|c|c|c|c|c|c|c|c|c|c|}
\hline \multirow[t]{2}{*}{ Preference of wild edible plants based on taste } & \multicolumn{18}{|c|}{ Informants labeled A to P } \\
\hline & A & B & C & D & E & $\mathbf{F}$ & G & $\mathrm{H}$ & I & J & K & L & M & $\mathbf{N}$ & 0 & $\mathbf{P}$ & Total score & Rank \\
\hline Carissa spinarium & 1 & 1 & 1 & 2 & 3 & 2 & 1 & 1 & 2 & 1 & 1 & 2 & 3 & 2 & 1 & 2 & 26 & 8th \\
\hline Cordia africana & 6 & 8 & 7 & 6 & 8 & 6 & 7 & 5 & 5 & 6 & 8 & 6 & 8 & 6 & 7 & 6 & 105 & 2nd \\
\hline Dovyalis abyssinica & 3 & 2 & 5 & 4 & 2 & 4 & 4 & 2 & 1 & 3 & 2 & 4 & 2 & 4 & 4 & 3 & 49 & 6th \\
\hline Ficus sur & 8 & 7 & 8 & 6 & 7 & 5 & 8 & 6 & 8 & 8 & 7 & 6 & 7 & 5 & 8 & 7 & 111 & $1 \mathrm{st}$ \\
\hline Ficus vasta & 4 & 3 & 2 & 1 & 1 & 1 & 2 & 3 & 3 & 4 & 3 & 1 & 1 & 1 & 2 & 4 & 36 & 7th \\
\hline Rosa abyssinica & 7 & 6 & 6 & 7 & 6 & 7 & 6 & 7 & 6 & 7 & 6 & 7 & 6 & 7 & 6 & 5 & 102 & $3 r d$ \\
\hline Rhus glutinosa subsp.glutinosa & 2 & 4 & 3 & 3 & 4 & 3 & 3 & 4 & 4 & 2 & 4 & 3 & 4 & 3 & 3 & 1 & 50 & 5th \\
\hline Rubus apetalus & 5 & 5 & 4 & 5 & 5 & 8 & 5 & 8 & 7 & 5 & 5 & 5 & 5 & 8 & 5 & 8 & 93 & 4th \\
\hline
\end{tabular}

\section{Preference Of Multipurpose Wild Edible Plants}

The output of the Direct Matrix Ranking (DMR) exercise on five multipurpose wild edible plants used based on five use categories enabled to identify which of the multipurpose plant was most under pressure in the areas, and the respective factors that threatened the plant. Accordingly, Carissa spinarum was ranked first (most threatened) (Table 3).

Table 3

Direct matrix ranking of 5 wild edible plants based on 5 use criteria by 4 key informants

\begin{tabular}{|c|c|c|c|c|c|c|c|c|c|c|c|c|c|c|c|c|c|c|c|c|c|c|c|c|}
\hline \multirow[t]{4}{*}{ Use category } & \multicolumn{24}{|c|}{ Wild edible plants } \\
\hline & \multicolumn{6}{|c|}{ Acacia abyssinica } & \multicolumn{6}{|c|}{ Carissa spinarum } & \multicolumn{6}{|c|}{ Cordia africana } & \multicolumn{6}{|c|}{ Olea europaea subsp. cuspidata } \\
\hline & \multicolumn{6}{|c|}{ Informants (I) (1-6) } & \multicolumn{6}{|l|}{ I } & \multicolumn{6}{|l|}{ I } & \multicolumn{6}{|l|}{ I } \\
\hline & 1 & 2 & 3 & 4 & 5 & 6 & 1 & 2 & 3 & 4 & 5 & 6 & 1 & 2 & 3 & 4 & 5 & 6 & 1 & 2 & 3 & 4 & 5 & 6 \\
\hline Environmental & 3 & 3 & 3 & 3 & 3 & 3 & 5 & 4 & 3 & 5 & 4 & 3 & 0 & 1 & 1 & 2 & 1 & 2 & 3 & 3 & 2 & 4 & 2 & 3 \\
\hline Fodder & 2 & 2 & 2 & 2 & 2 & 2 & 2 & 1 & 1 & 2 & 1 & 1 & 3 & 3 & 2 & 3 & 2 & 3 & 0 & 0 & 0 & 0 & 0 & 0 \\
\hline Fuel & 4 & 4 & 4 & 4 & 4 & 4 & 1 & 2 & 2 & 1 & 2 & 2 & 1 & 1 & 2 & 2 & 1 & 1 & 2 & 2 & 4 & 3 & 1 & 2 \\
\hline Medicine & 0 & 0 & 0 & 0 & 0 & 0 & 4 & 5 & 4 & 5 & 5 & 4 & 0 & 0 & 0 & 0 & 0 & 0 & 1 & 2 & 3 & 4 & 5 & 3 \\
\hline Social & 5 & 5 & 5 & 5 & 5 & 5 & 3 & 3 & 5 & 2 & 3 & 5 & & 5 & 5 & 5 & 5 & 5 & 5 & 5 & 5 & 5 & 5 & 5 \\
\hline $\begin{array}{l}\text { Informant } \\
\text { total }\end{array}$ & 15 & 16 & 17 & 18 & 19 & 20 & 16 & 17 & 18 & 19 & 20 & 21 & 5 & 12 & 13 & 16 & 14 & 17 & 12 & 14 & 17 & 20 & 18 & 19 \\
\hline Grand & 105 & & & & & & 111 & & & & & & 77 & & & & & & 100 & & & & & \\
\hline Rank & 2nd & & & & & & $1 \mathrm{st}$ & & & & & & 5 th & & & & & & 4th & & & & & \\
\hline
\end{tabular}

Note: ( 5 = Best; 4 = Very good; 3 = Good; 2 = Less used; 1 = Least used and 0 = No value).

\section{Use Diversities}

Wild edible plants were also reported to have other roles for the local community of the Districts. These were source of traditional medicine, fodder, firewood, charcoal, poison and construction materials. Wild edible plants were a source of forage for cattle and bees (becoming source of nectar for bees). The most commonly reported forage edible plants for bees were Vernonia amygdalina whereas Vernonia amygdalina, Cordia africana, Rosa abyssynica, Cyperus rigidifolius, Persicaria nepalensis, Acacia abyssinica and Acanthus sennii were the most commonly used forage edible plants for livestock. They had also environmental uses such as soil conservation, increment of soil fertility, fence (dry and live fence). Acanthus sennii, Carissa spinarum, Opuntia ficus indica, Urtica simensis and Rosa abyssincia were reported to be the most commonly used species for live fence while Cordia africana was reported to be the most commonly mentioned species for soil fertility. However, most of the species were used as a source of fuel wood (firewood and charcoal). 


\section{Market Surveys On Wild Edible Plants}

The results further indicated that fruits of some wild edible plants such as Mimusops kummel and Ficus sur and Ximenia americana were observed to be sold in local markets of the districts (Fig. 5). Mimusops kumme/ was observed in Adet market starting from November - April while Ficus surwas observed in Bir Gebeya (in Yilmana Densa district), Dabi and Adet market rarely in smaller market places starting from March to the end of May. Mimusops kumme/ was reported to be sold in a can (almost it may contain $1 / 2$ kilo gram). A single can of its fruits were sold by 3 Birr (Ethiopian Birr) or by count, 10 fruits were sold by 1 Birr. The figs of Ficus vasta, and the fruits Ximenia americana and Ensete ventricosum were reported to be rarely sold in local markets.

However, most of wild foods (81.3\%) were non-marketable. This indicated that the local community of the districts had low culture of using wild edibles as a complementary food. This might be one of the reasons that wild foods were mostly consumed by households while there was a collapse in the harvest of cultivated food crops because of drought as reported in other areas [24, 25]. According to [22], the low affinity in using wild edible foods as complementary food indicates the presence of low awareness rising on the use and management of wild edible plants.

\section{Threats And Conservation}

Agricultural land expansion was the primary threat to wild edible plants of the districts as it was recorded as a primary threat in other parts Ethiopia [23]. The other main threats were cutting trees for fuel wood and over grazing in agreement with other findings [26, 27, 28]. The increasing demand of firewood might be interrelated with directly degrading forests or it might be accompanied by the replacement of forest patches by fast growing monoculture non-native trees [29]. According to [30], the increasing demand for firewood and construction material created dependable markets for Eucalyptus products which have contributed to the steady expansion of its area in the region. The major conservation activities practiced by the local people in the districts were planting trees. The local people usually cultivate wild edible plants for indirect uses such as income generation, fence, timber, aesthetic, shade and soil conservation. Cordia africana, a well known timber plant, was conserved by such types of activities in agreement with other findings [31]

\section{Conclusions}

The districts have appreciable amount of wild edible plants which are a source of high amount of wild foods. The remnant forests of the districts were also the home for most the collected edible species. Thus, conservation priority should be given for the forests of the areas. The other main point here is that the culture of the people in using wild edible plants as a supplementary food is low. Thus, there should be an extensive awareness rising in using wild edible foods. This might be also an incentive to the local people to appraise for conservation. In addition, nutritional analysis tests should also be conducted to identify whether which species are enriched in essential nutrients.

\section{Declarations}

\section{Acknowledgements}

I am very much indebted to all the local informants who shared their traditional wild edible plant knowledge for me.

\section{Ethics approval and consent to participate}

Prior to data collection, participants gave oral consent to participate in the study.

\section{Consent for publication}

The respondents were informed that their opinions were to be published in a scientific paper and gave their approval.

\section{Author's contributions}

The author has read and approved the final manuscript.

\section{Funding}

No funding is applicable.

\section{Availability of data and materials}

The datasets supporting the conclusions of this article are included in the Appendix 1.

\section{Competing interests}

The author declares that he has no competing interests.

\section{References}

1. FAO (Food and Agriculture Organization of the United Nations) (1995). Non-wood forest products for rural income and sustainable forestry. Non-wood forest products. Rome, Food and Agriculture Organization of the United Nations, 7.

2. Bell, J. (1995). The hidden harvest. In seedling, the quarterly newsletter of genetic resources action international. 
3. Burlingame, B. (2000). Wild nutrition. Journal of Food Composition and Analysis, 13: 99-100.

4. Gordon, L. J. and Enfors, E. I. (2008). Land degradation, ecosystem services and resilience of smallholder famers in Makanya catchment, Tanzania.

5. Fentahun Mengistu and Hager, H. (2008). Wild edible fruit species cultural domain, informant species competence and preference in three districts of Amhara region, Ethiopia. Ethnobotany research and applications, 6: 487502.

6. Grivetti, L. and Ogle, B. (2000). Value of traditional foods in meeting macro and micronutrient needs: the wild plant connection. Res. Rev. 13 : 31-46.

7. Mekdes Ourge, Hofstad, O., Klanderud, K., Eldegard, K. and Sarah Tewolde-Berhan (2018). Illegal harvesting of locally endangered Olea europaeacuspidata (Wall. ex G. Don) Cif and its causes in Hugumburda forest, Northern Ethiopia. Forests, 9: 498.

8. Dawit Abebe and Ahadu Ayehu (1993). Medicinal Plants and Enigmatic Health Practices of Northern Ethiopia. Monograph, Addis Ababa.

9. Hurni, H., Solomon Abate, Amare Bantider, Berhanu Debele, Ludi, E., Portner, B., Birru Yitaferu and Gete Zeleke. Land degradation and sustainable land management in the Highlands of Ethiopia. In: Hurni H, Wiesmann U, editors; with an international group of coeditors. Global Change and Sustainable Development: A Synthesis of Regional Experiences from Research Partnerships. Perspectives of the Swiss National Centre of Competence in Research (NCCR) North South, University of Bern, 2010, 5. Bern, Switzerland: Geographica Bernensia.

10. Hurni, H.. Agroecological Belts of Ethiopia: Explanatory Notes on Three Maps at a Scale of 1:1,000,000. Soil Conservation Research Programme (SCRP) Research Report No. 43. Addis Abeba, Ethiopia and Bern, Switzerland: Ministry of Agriculture and Centre for Development and Environment (CDE), 1998.

11. AOD (Agricultural office of the District), 2016.

12. Central Statistical Agency (CSA) (2007). 2007 Population and Housing Census of Ethiopia: Results for Amhara Region, 2007, Vol. 1, part 1. Tables: Amhara Region. Tables 2.1, 2.4, 2.5, 3.1, 3.2 and 3.4.

13. Israel, G. D. Sampling. The Evidence of Extension Program Impact. Program Evaluation and Organizational Development, IFAS, University of Florida, 1992.

14. Martin, G.J. (1995). Ethnobotany: A methods manual. Chapman and Hall, London.

15. Albuquerque, U. P., da Cunha, L. V. F. C., de Lucena, R. F. P. and Alves, R. N. eds. Methods and Techniques in Ethnobiology and Ethnoecology. Springer Protocols Handbooks, New York, 2014.

16. Alexiades, M. Collecting ethnobotanical data. An introduction to basic concepts and In: (Alexiades, M. and Sheldon, J.W.eds.). Selected Guideline for ethnobotanical research: A Field Manual, 1996, The New York. Botanic Garden, U.S.A. Pp.58-94.

17. Cotton, M. C. (1996). Ethnobotany: Principles and Applications. Roehampton Institute London, UK.

18. Phillips, O. (1996). Some quantitative methods for analyzing ethnobotanical knowledge. In: Alexiades M (ed) Selected guidelines for ethno-botanical research: a field manual. The New York Botanical Garden, New York, pp 171-197.

19. Byg, A. and Baslev, H. (2001). Diversity and use de palms in Zahamena, eastern Madagascar. Biodiversity and Conservation 10:951-970.

20. Mahapatra, K. A., Mishra, S., Basak, C. U. and Panda, C. P. (2012). Nutrient Analysis of Some Selected Wild Edible Fruits of Deciduous Forests of India: an Explorative Study towards non-conventional bio-nutrition. Advance Journal of Food Science and Technology, 4 (1): $15-21$.

21. Nayak, J. and Basak, U. C. (2015). Analysis of some nutritional properties in eight wild edible fruits of Odisha, India. Int J Curr Sci, 14: 55-62.

22. Debela Hundie, Njoka, J, T., Nyangito, M. M. and Zemede Asfaw (2011). Neutraceutal Wild Plants of Semiarid East Shewa, Ethiopia: contributions to food and healthcare security of the semiarid people. Research Journal of Forestry 5(1): 1-16.

23. Getachew Addis, Zemede Asfaw and Zerihun Woldu (2013a). Ethnobotany of wild and semi-wild edible plants of Konso ethnic community, south Ethiopia. Ethnobotany research and applications, 11:121-141.

24. Zemede Asfaw (1997). Survey of Indigenous food plants, their preparations and homegardens in Ethiopia. In: Indigenous African food Crops and useful Plants. UNU/IRNA Assessment series No. B6.N. Okigbo (series editor).

25. Tigist Wondimu, Zemede Asfaw and Ensermu Kelbessa (2006). Ethnobotanical study of food plants around 'dheeraa' town, Arsi, Ethiopia. J. Sci., 29(1):71-80.

26. Million Bekele and Leykun Berhanu (2011). Forest genetic resources working papers: state of forest genetic resources in Ethiopia. The sub-regional workshop FAO/IPGRI/ICRAF on the conservation, management, sustainable utilization and enhancement of forest genetic resources in Sahelian and north-Sudanian Africa.

27. Samuale Tesfaye, Etefa Guyassa, Raj, J. A., Emiru Birhane and Gebeyehu Taye (2014). Land use and land cover change, and woody vegetation diversity in human driven landscape of Gilgel Tekeze catchment, northern Ethiopia. International Journal of Forestry Research.

28. Birhanu Woldie, Berhanu Abraha and Birhanu Belay (2015). Survey on composition of perennial vegetation in Sesa Mariam monastery, northwestern Ethiopia. BMC Res Notes, 8: 622.

29. Addisu Asefa, Yosef Mamo, Girma Mengesha and Anteneh Shimelis (2015). Woody plant diversity along disturbance gradients in the northern Afromontane forests of the Bale mountains, Ethiopia. International Journal of Development Research, 5 (03):3745-3754.

30. Gessesse Dessie and Teklu Erkossa (2011). Planted forests and trees working papers: Eucalyptus in east Africa: socio - economic and environmental issues. FAO, Rome, Italy.

31. Fisseha Mesfin, Talemos Seta and Abreham Assefa (2014). An ethnobotanical study of medicinal plants in Amaro district, Ethiopia. Ethnobotany Research and Applications 12: 341-354.

\section{Figures}




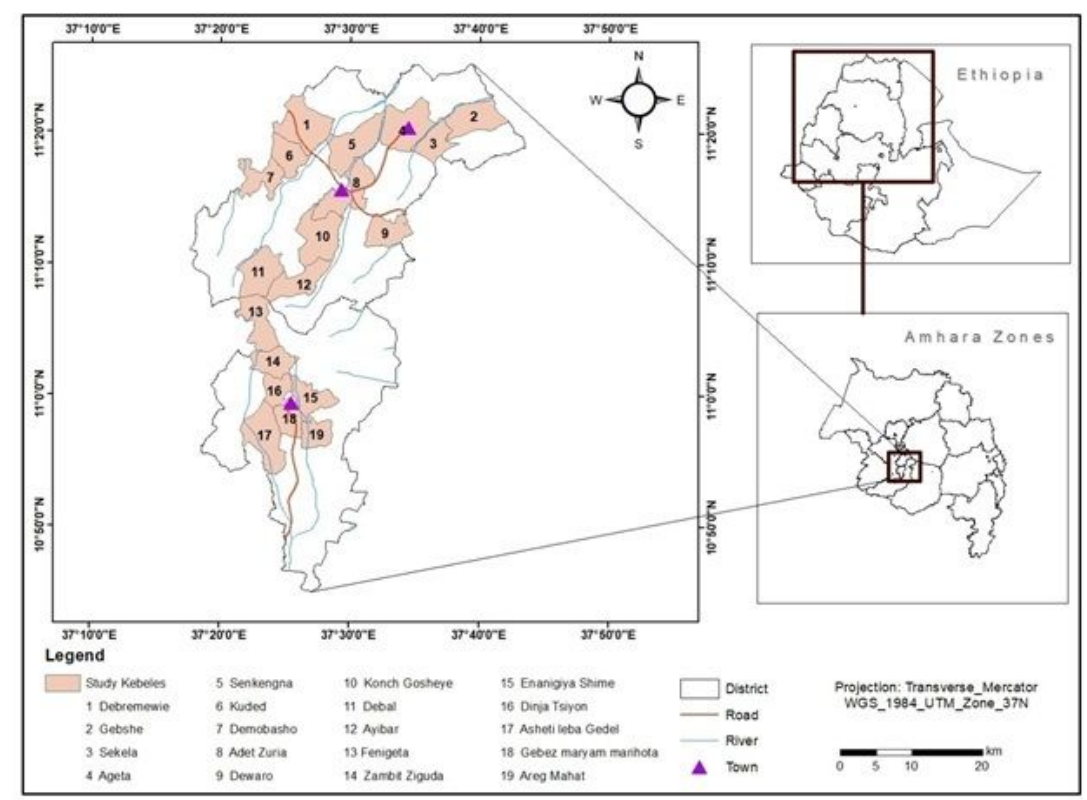

Figure 1

Map of the study Districts and Kebeles (Drawn by using Arc GIS ver. 10.5).

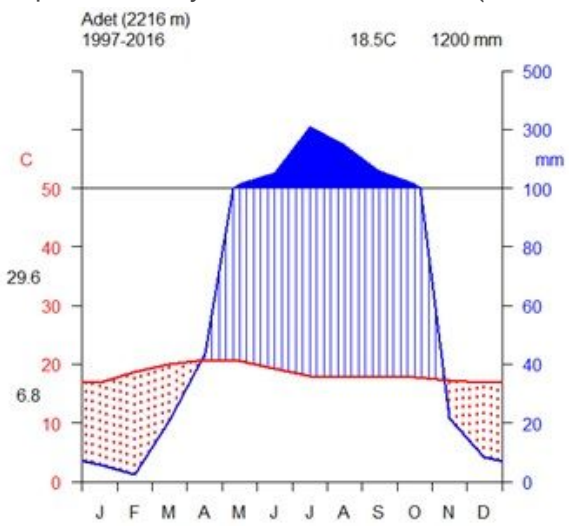

Figure 2

Climate diagram of Adet

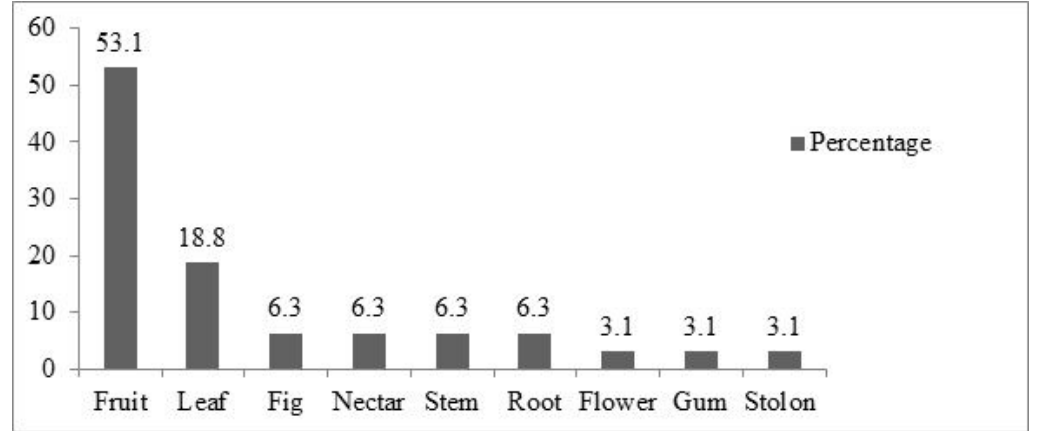

Figure 3

Percent of edible parts 
A.
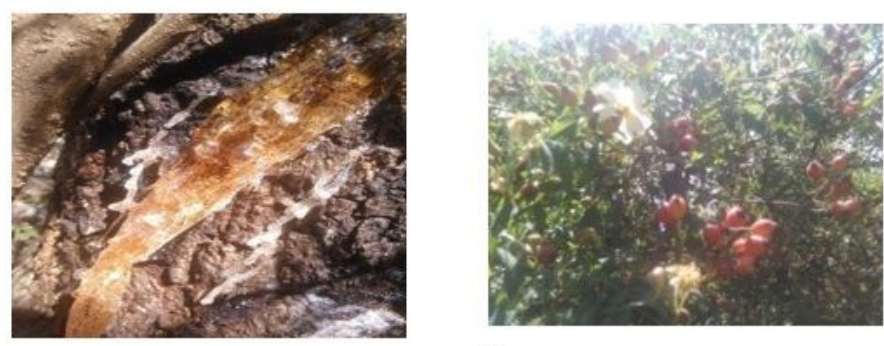

B

\section{Figure 4}

Acacia abyssinica gum (A) from Asheti Leba Gedel Kebele and the fruits of Rosa Abyssinica (B) from Gebez Maryam kebele

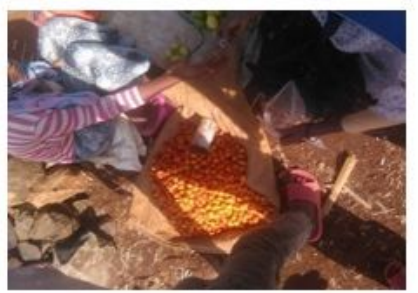

\section{Figure 5}

Fruits of Mimusops kummel in Adet market presented for sell

\section{Supplementary Files}

This is a list of supplementary files associated with this preprint. Click to download.

- Appendix1Wildedibleplants.docx 